\title{
Roles of the calcium sensing receptor in digestive physiology and pathophysiology (Review)
}

\author{
RUI XIE, BO TANG, XIN YONG, GANG LUO and SHI-MING YANG \\ Department of Gastroenterology, Xinqiao Hospital, Third Military Medical University, Chongqing 400037, P.R. China
}

Received February 14, 2014; Accepted April 30, 2014

DOI: $10.3892 / \mathrm{ijo} .2014 .2560$

\begin{abstract}
Calcium participates in most of the biological processes in the human body. The calcium sensing receptor (CaSR), as an important regulator of calcium homeostasis, is expressed in all of the organs of the digestive system. CaSR plays a key role in gastrointestinal physiological function and in the occurrence of digestive disease. For example, the inactivation or mutation of the CaSR gene usually leads to one of several disorders of calcium metabolism. High dietary $\mathrm{Ca}^{2+}$ may stimulate CaSR activation and could both inhibit tumor development and increase the chemotherapeutic sensitivity of cancer cells in colon cancer tissues. Further, CaSR has also been reported to have a potential role in the treatment for diarrheal diseases and the form of pancreatitis that is associated with carbonate stones. Therefore, CaSR is an important target for treating digestive diseases, and the calcimimetics (CaSR agonist) have been confirmed as practical, feasible and effective clinical therapies for hyperparathyroidism. This review intends to explore the role of CaSR in digestive physiology and pathophysiology as well as current treatments utilizing CaSR-based therapeutics.
\end{abstract}

\section{Contents}

1. Introduction

2. The structural features of CaSR

Correspondence to: Professor Shi-Ming Yang, Department of Gastroenterology, Xinqiao Hospital, Third Military Medical University, Chongqing 400037, P.R. China

E-mail: shimingyang@yahoo.com

Abbreviations: CaSR, calcium sensing receptor; ECD, extracellular domain; TMD, transmembrane domain; VDRE, vitamin D response elements; TRPC, transient receptor potential; ER, endoplasmic reticulum; MAPKs, mitogen activated protein kinases; PI3K/AKT, phosphatidylinositol 3 kinase/protein kinase B; CX-CL8, multifunctional cytokine IL-8; FGF9, fibroblast growth factor 9; E-cadherin, epithelial adhesion protein; VGCC, voltage-gated $\mathrm{Ca}^{2+}$ channels; VDCC, voltage-dependent $\mathrm{Ca}^{2+}$ channel; SPNIK1, pancreatic secretory trypsin inhibitor gene; PKC, protein kinase C; hTERT, human telomerase reverse transcriptase; MMC, mitomycin C; 5-FU, 5-fluorouracil

Key words: calcium, calcium sensing receptor, digestive, ion channel, therapy
3. The distribution of CaSR and its function in $\mathrm{Ca}^{2+}$ homeostasis and cellular processes

4. Role of CaSR in the esophagus

5. CaSR in the liver

6. CaSR and the pancreas

7. CaSR expression in the stomach

8. CaSR expression and function in the intestines

9. Conclusions

\section{Introduction}

$\mathrm{Ca}^{2+}$ is a ubiquitous cellular signal. Changes in intracellular $\mathrm{Ca}^{2+}$ control various cellular processes that are relevant to regulating normal function and to developing diseases. Examples of such processes include blood coagulation, nervous excitation, angiogenesis, cell apoptosis and the development of cancer (1). $\mathrm{Ca}^{2+}$ also plays an important role in the physiological function and pathological processes of the digestive system. The calcium-sensing receptor $(\mathrm{CaSR})$ is a member of the $\mathrm{G}$ protein-coupled receptor (GPCR) C superfamily and plays a key role in maintaining systemic calcium homeostasis (2). It is expressed in diverse mammalian tissues, including the parathyroid gland, the cardiovascular system and the entire digestive system (3), and it mediates insulin and gastric acid secretions as well as intestinal fluid transport (4). A mutation in the CaSR gene might be a predisposing factor that leads to an increased susceptibility of chronic and recurrent acute pancreatitis (5). Further, the CaSR gene is believed to be an antitumor factor and is decreased or even absent in adults with colorectal cancer (34). However, the mechanism and function of CaSR in the gastrointestinal tract have not yet been completely elucidated, particularly relating to certain digestive diseases and tumors. To support CaSR-based therapeutics of digestive diseases, we need to deepen our understanding of CaSR structure and its biochemical features and to determine the role of CaSR in the physiological and pathophysiological processes of the gastrointestinal system.

\section{The structural features of CaSR}

$\mathrm{CaSR}$, a member of the $\mathrm{C}$ family of $\mathrm{G}$ protein-coupled receptors (GPCR), was first cloned from the bovine parathyroid gland (6). The human CaSR gene is located on the long arm of chromosome 3, and it encodes a polypeptide composed of 1,078 amino acids. CaSR can be divided into three parts: the extracellular 
domain (ECD), the transmembrane domain (TMD) and the intracellular domain. The extracellular domain (ECD) (N terminal) includes 612 amino acids, which contains the binding site of $\mathrm{Ca}^{2+}$ or a CaSR agonist. The transition from the activation to the deactivation of CaSR mostly occurs in the ECD. Similar to other GPCRs, CaSR has a 250-amino-acid transmembrane domain (TMD) that has 7 transmembrane helices $(7,8)$. A cysteine-rich domain exists between the ECD and the first transmembrane of TMD, removing this domain results in the loss of CaSR signaling (9). The final 216 amino acids form the intracellular tail (C terminal) that contains protein kinase C, A and D phosphorylation sites (7). CaSR agonists include polyvalent metal cations (such as $\mathrm{Ca}^{2+}$ and $\mathrm{Gd}^{3+}$ ) and organic polycations such as polylysine, protamine and L-amino acids.

Because the concentration of $\mathrm{Ca}^{2+}$ in the blood does not change obviously, the complex structure and many binding sites of CaSR are required to monitor and regulate the blood $\mathrm{Ca}^{2+}$ concentration. $\mathrm{Hu}$ and Spiegel (8) and Huang et al (10) reported that the molecular structure of the ECD of CaSR is bilobed, where every two ECDs form a Venus flytrap (VFT) that has a binding site for $\mathrm{Ca}^{2+}$ in the crevice of the two lobes. The TMD also contains the $\mathrm{Ca}^{2+}$ binding site to regulate when the ECD is inactivated (11). Several transcription factors take part in modulating the activation of CaSR, such as vitamin D response elements (VDRE), Stat1/3, NFאB and Sp1/3, and their binding sites are located in the CaSR promoters $(12,13)$.

\section{The distribution of $\mathrm{CaSR}$ and its function in $\mathrm{Ca}^{2+}$ homeostasis and cellular processes}

To date, studies have confirmed the important role of CaSR in $\mathrm{Ca}^{2+}$ homeostasis $(2,14)$, indicating that CaSR is expressed in most organs that regulate the $\mathrm{Ca}^{2+}$ balance, including the parathyroid glands, kidney, thyroid C cells, stomach, osteoblasts and osteoclasts (15-17). CaSR was also shown to be widely expressed in the nervous system, esophagus, liver, pancreas, pituitary gland, peripheral blood, breast and arterial smooth muscle cells $(15,18-20)$. It is well known that several factors affect the mechanism of $\mathrm{Ca}^{2+}$ homeostasis, including $\mathrm{Ca}^{2+}$ sensors in the cell membrane and $\mathrm{Ca}^{2+}$ regulating hormones. $\mathrm{CaSR}$ is an important $\mathrm{Ca}^{2+}$ sensor that not only regulates the release of $\mathrm{Ca}^{2+}$ from the endoplasmic reticulum (ER) but also controls the switch of the $\mathrm{Ca}^{2+}$ ion channel in the cellular membrane, which allows the transport of $\mathrm{Ca}^{2+}$ into or out of the extracellular fluid (21,22). For example, CaSR activation can mediate $\mathrm{Ca}^{2+}$ entry into human aortic smooth muscle cells via transient receptor potential 6 (TRPC6) (21). TRPC3, another member of the TRPC family, was proved to participate in the CaSR mediation of $\mathrm{Ca}^{2+}$ overload in the heart (23). In addition, hormones play an important role in regulating $\mathrm{Ca}^{2+}$ balance. $\mathrm{CaSR}$ has been proven to regulate the secretion and production of hormones, including parathyroid hormone (PTH), calcitonin (CT), and 1,25-dihydroxyvitamin D 3 [1,25(OH)23], that maintain $\mathrm{Ca}^{2+}$ homeostasis $(24,25)$. Taken together, in physiological conditions, $\mathrm{CaSR}$ is critical to the $\mathrm{Ca}^{2+}$ balance in the human body.

The CaSR acts through at least two $\mathrm{G}$ proteins $\left(\mathrm{G} \alpha_{\mathrm{i}}\right.$ and $\left.\mathrm{G} \alpha_{\mathrm{q} / 11}\right)$ to regulate multiple intracellular second messengers, including inositol trisphosphate $\left(\mathrm{IP}_{3}\right)$, cytoplasmic free $\mathrm{Ca}^{2+}$ $\left(\left[\mathrm{Ca}^{2+}\right]_{\text {cyt }}\right)$ and cyclic adenosine monophosphate (cAMP) (26).
The activated CaSR can stimulate the phospholipase $\mathrm{C}$ (PLC-IP3) signal pathway to prompt the release of $\mathrm{Ca}^{2+}$ from endoplasmic reticulum (ER) (27). The intracellular signal pathways including mitogen activated protein kinases (MAPKs), phosphatidylinositol 3 kinase/protein kinase B (PI3K/AKT), and phospholipases A, C and D can also be activated by the activation of CaSR $(27,28)$, they then regulate several cellular processes that are involved in cellular secretion, proliferation, differentiation, chemotaxis, apoptosis, gene expression, ion channel switch and aging $(3,29,30)$. Numerous transcription factors participate in the complex regulation process that depends on CaSR. For example, activated CaSR can regulate the cyclin D family genes, c-Myc and c-Fos to affect cell proliferation $(31,32)$, and $\mathrm{NF} \mathrm{B}$ can also be stimulated by CaSR to promote the secretion of proinflammatory factors and chemokines that cause the development of obesity induced adipose tissue dysfunction disease (33). CaSR was reported to decrease $\beta$-catenin-TCF- 4 complex formation and thus suppress the development of tumors in colon cancer (34). In summary, the CaSR is considered to be a critical player in cellular processes.

\section{Role of CaSR in the esophagus}

CaSR is known to be expressed in the basal cells of the human esophagus and in the non-tumorigenic esophageal epithelial cell line HET-1A $(35,36)$. In the study of the HET-1A cell line, activated CaSR increases intracellular $\mathrm{Ca}^{2+}$ concentration mobilization and activates ERK1/2 (MAPK) signal pathways to promote the multifunctional cytokine IL-8 (CX-CL8) secretion (36). In oesophagitis, Mulder et al proved that CaSR can be activated by eosinophil-released major basic protein (MBP) to promote fibroblast growth factor 9 (FGF9) secretion and that it then affects the downstream proliferation-related genes BMP-2 and BMP-4 to induce the proliferation of esophageal epithelial cells (37). CaSR may be implicated in the proliferative response to injury and the pathogenesis of oesophagitis. However, it is not yet known whether the CaSR activation affects the proliferation or differentiation of cancer cells in animals or human esophageal cancer.

\section{CaSR in the liver}

Much evidence shows that CaSR is important for normal hepatic physiological function and liver diseases. In 2001, Canaff et al first identified expression in liver tissue and primary cultured hepatocytes (20). Subsequently research demonstrated the functional expression of CaSR in Buffalo rat liver cells and that activated CaSR stimulated bile flow by the PLC-IP3 signal transduction pathway (38). In the hepatic ischemia/reperfusion (I/R) injury model, CaSR activation induced cell apoptosis by promoting the p38 MAPK and ERK-1/2 signal pathway phosphorylation and regulating the downstream Bcl-2, Cyt-c, caspase-3 and Bax gene expression (39). More importantly, in the cirrhotic animal model which was induced by carbon tetrachloride $\left(\mathrm{CCl}_{4}\right), \mathrm{CaSR}$ has been reported to reduce the intrahepatic resistance to portal flow (40). Thus, the regulation of CaSR might serve as a new pharmacological target for the prevention and treatment of drug- or alcohol-induced liver disease. 


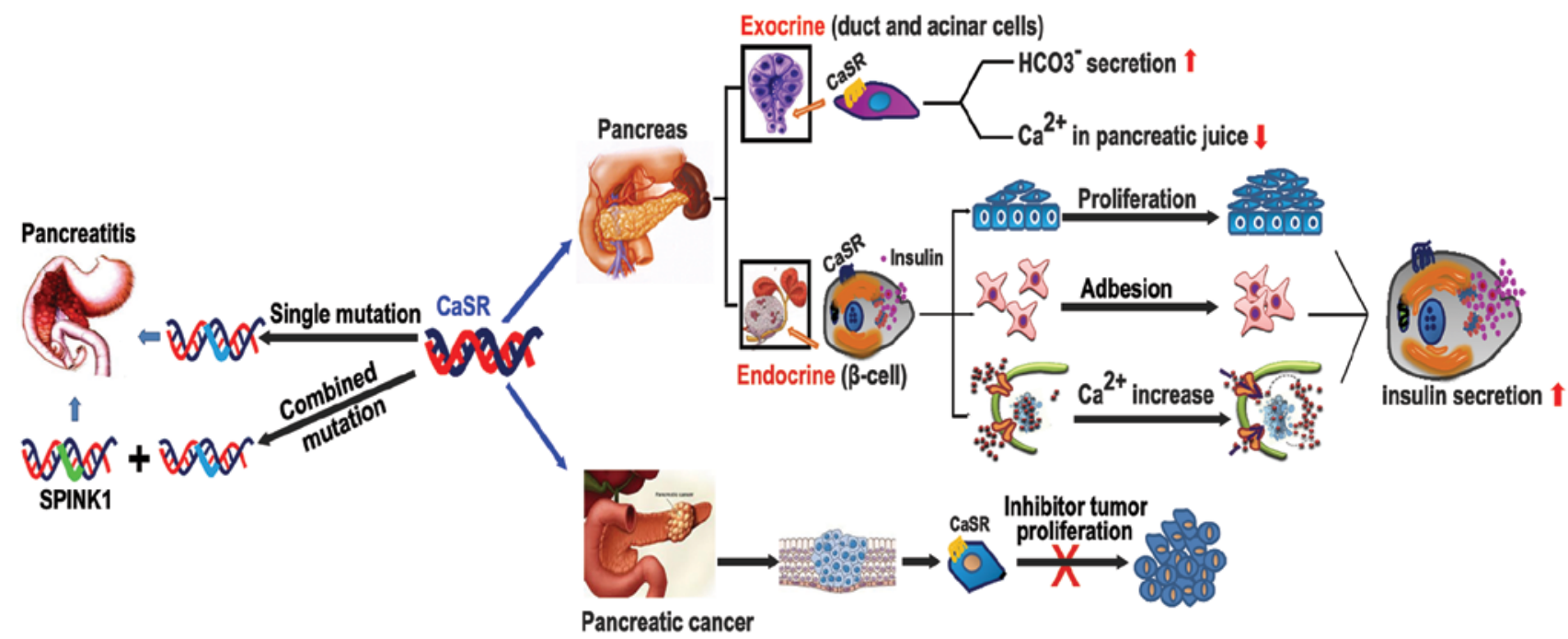

Figure 1. Schematic representation of the CaSR showing the known function in pancreas physiology and pathophysiology. Activation of the CaSR can modulate ductal $\mathrm{HCO}^{-}$secretion and $\mathrm{Ca}^{2+}$ concentration in pancreatic juice. CaSR could stimulate the $\beta$-cell proliferation, cell-cell communication and intracellular $\mathrm{Ca}^{2+}$ release to co-lead the insulin release. In addition, CaSR suppresses cell proliferation in pancreatic cancer, and the mutations of CaSR with or without SPINK1 both lead to pancreatitis.

\section{CaSR and the pancreas}

In 2002, Rácz et al (19) were the first to report evidence for the presence of CaSR in the normal human pancreas, pancreatic cancer and chronic pancreatitis tissue. Immunohistochemistry located the expression of CaSR in the endocrine and exocrine pancreas, including $\beta$-islet cells, duct cell, acinar cells and various non-exocrine cells such as intrapancreatic nerves and blood vessels $(19,41)$. These data suggest that CaSR has a function in the human pancreas. However, the CaSR function varies depending on where it is located in the pancreas (Fig. 1).

CaSR in exocrine and endocrine pancreas physiology. The function of the exocrine pancreas mainly include the secretion of various digestive enzymes and pancreatic juice. CaSR was observed to be highly expressed in human pancreatic acinar and ducts cells (19), suggesting a potential role for CaSR in regulating pancreatic exocrine function. In 1999, Bruce et al reported that the activation of CaSR in the rat pancreas duct luminal membrane increased ductal $\mathrm{HCO}^{-}$secretion (41). Moreover, CaSR could monitor and regulate the $\mathrm{Ca}^{2+}$ concentration in pancreatic juice by triggering ductal electrolyte and fluid secretion, thereby reducing the precipitation of $\mathrm{Ca}^{2+}$ salts in the duct lumen and decreasing both the risk of carbonate stone formation and the progression to pancreatitis (19). Although the expression of CaSR could be detected in human acinar cells (42), the function of the receptor in this setting is not yet clear.

The function of CaSR in pancreatic endocrine tissue is confirmed to participate in the regulation of glucose-induced insulin secretion by $\beta$-cells (42-44). It is known that change in plasma glucose concentration is the major factor stimulating insulin release. The metabolism of glucose could change the ATP/ADP ratio by closing ATP-dependent $\mathrm{K}^{+}$channels that then open the voltage-gated $\mathrm{Ca}^{2+}$ channels (VGCC) to mediate intracellular $\mathrm{Ca}^{2+}$ changes and induce insulin release (45). The extracellular $\mathrm{Ca}^{2+}$ levels were previously observed to induce transitory increases in insulin secretion (46). The experiments of Squires et al (45) and Gray et al (47) in human islets and insulin-secreting cell lines (MIN6) also confirmed that low concentrations of $\mathrm{Ca}^{2+}$ could induce a marked but transient insulin secretion by activating the CaSR and the downstream MAPK signal pathway. In addition, CaSR was shown to affect the $\beta$-cell proliferation and cell-cell communication that cooperate in insulin secretory responses (48). Hills et al showed that CaSR was able to enhance the function of the epithelial adhesion protein (E-cadherin) in $\beta$-cells and the expression of L-type VDCC, which reinforces cell-cell adhesion and $\beta$-cell function to promote the insulin secretion of neighboring cells. However, the role of CaSR is dual because they have a functional that varies between enhancing and inhibiting insulin release. Studies have shown that CaSR in human $\beta$-cells have a negative modulatory effect on insulin secretion (43). First, the CaSR is activated by extracellular $\mathrm{Ca}^{2+}$ which is a promotive factor for insulin secretion, but if there is a prolonged $\mathrm{Ca}^{2+}$ concentration-dependent activation, this is reversed and inhibition of insulin secretion is affected. Moreover, the transduction mechanism is confirmed to be unlikely through the cAMP or PLC-IP3 pathways. Squires et al (43) proposed that coupled receptor is the possible mechanism for insulin secretion inhibition, but they have not yet garnered enough evidence to prove this hypothesis. Although it has been reported that the colocalization and the spatial interactions between the L-type voltage-dependent calcium channels (L-type VDCC) and CaSR enhanced the glucose-induced the secretion of insulin (45), the latest report found that the CaSR that is activated by L-histidine depresses L-type VDCC activity and inhibits insulin secretion in $\beta$-cells (49). Thus, the different stimulation factors and space conformational changes of CaSR may be a possible explanation for the role of CaSR in negatively modulating insulin secretion.

The role of CaSR in pancreatic disease. Recent studies have primarily focused on the acute and chronic pancreatitis (CP) 
associated with CaSR receptor mutation $(6,50,51)$. The mutations in the CaSR gene and the pancreatic secretory trypsin inhibitor gene (SPINK1) were identified in patients with familial hypocalciuric hypercalcemia (FHH), in 2010, genetic linkage and candidate gene studies recognized that these two gene mutations were associated with susceptibility to acute and/or chronic pancreatitis $(51,52)$. Felderbauer et al found that mutations of the CaSR gene (R896H) were particularly associated with SPINK1-related chronic pancreatitis (51). Clinical research has suggested that pancreatitis patients usually have both the CaSR mutation and the N34S SPINK1 gene mutation, whereas in healthy patients, only an isolated CaSR or N34S SPINK1 gene mutation can be detected. This finding suggests that the CaSR gene is an important co-factor in SPINK1-related pancreatitis. In 2008, Murugaian et al found that four new mutations of the CaSR gene in patients in India with tropical chronic pancreatitis, which confirmed that CaSR variants could lead to idiopathic $\mathrm{CP}$ with or without SPINK1 mutations (53). Moreover, some literature has elucidated the role of CaSR in pancreatic cancer. CaSR was detected in human pancreatic cancer tissue and cell lines. Early studies reported that CaSR is activated by elevated extracellular $\mathrm{Ca}^{2+}$ or $\mathrm{Gd}^{3+}$ that can significantly reduce cell proliferation in the well-differentiated human pancreatic adenocarcinoma capan-1 cell line (19), but these results were obtained in vitro. More clinical evidence is needed to determine the role of CaSR in pancreatic tumors.

\section{CaSR expression in the stomach}

The regulatory function of $\mathrm{Ca}^{2+}$ and CaSR in gastric acid secretion. The stomach is an important digestive organ. Gastric acid plays an indispensable role in modulating digestion and absorption, and an imbalance usually induces gastrointestinal disease (54). Generally, the classically modulated pathways of acid secretion are involved including the paracrine, endocrine, and neuroendocrine systems (55), in addition, the $\mathrm{H}^{+}-\mathrm{K}^{+}$-ATPase activation was also shown to be crucial to the formation of $\mathrm{HCL}$ and the regulation of gastric acid secretion $(56,57) . \mathrm{Ca}^{2+}$ is an important second messenger and has a role in the above process. In previous animal and human studies, experiments have proved that $\mathrm{Ca}^{2+}$ and amino acids are useful in stimulating acid secretion. High levels of intravenous or intestinal $\mathrm{Ca}^{2+}$ both promote the release of gastric acid (57,58). Interestingly, we found that gastric acid increases that are induced by hormonal or neuronal stimulation accompany an elevation in intracellular $\mathrm{Ca}^{2+}$ levels that can be detected in the gastric gland $(59,60)$. Thus, there is a close connection between $\mathrm{Ca}^{2+}$ and gastric acid secretion, and the CaSR is confirmed to participate in the regulation of $\mathrm{Ca}^{2+}$-induced gastric acid secretion.

The role of CaSR in regulating gastric acid secretion has been proven in both in vivo and in vitro experiments, and gastric cells of the basement membrane, mucus cells, $\mathrm{G}$ cells and D cells all express CaSR (61). Ceglia et al provided the first in vivo evidence that the activation of the CaSR increases the serum gastrin levels and basal gastric acid secretion in healthy older men and women (62). Activated CaSR increased the intracellular $\mathrm{Ca}^{2+}$ concentration by leading to a release of $\mathrm{Ca}^{2+}$ from the ER and causing an influx of extracellular $\mathrm{Ca}^{2+}$. The elevated intracellular $\mathrm{Ca}^{2+}$ level enhanced parietal cell $\mathrm{H}^{+}-\mathrm{K}^{+}$-ATPase activity and subsequently gastric acid secre- tion $(62,63)$. Further study showed that in isolated human gastric glands, the signal pathway PLC-IP3 and ERK1/2 (MAPK) as well as $\mathrm{Ca}^{2+}$-dependent and $\mathrm{Ca}^{2+}$-independent protein kinase $\mathrm{C}(\mathrm{PKC})$ isoforms participate in CaSR activation and cause acid secretion (64). The regulation of gastrin release is another important pathway by which CaSR moderates acid secretion. Research has shown that the $\mathrm{G}$ cells expressing CaSR were sensitive to amino acids, $\mathrm{pH}$ and elevated levels of $\mathrm{Ca}^{2+}$ and that these cells secreted gastrin in the presence of these factors (4). Double immunofluorescence studies validated the specific colocalization of gastrin and CaSR in CaSR wildtype (WT) mice. The lower extracellular $\mathrm{Ca}^{2+}$ concentrations activate CaSR to produce a proliferative response in normal human gastric mucous epithelial cells $(65,66)$. Thus, a close connection may exist between CaSR and gastrin. Indeed, many experiments showed that CaSR was highly expressed on human gastrinoma cells and that activated CaSR could increase the release of gastrin $(67,68)$. Taken together, these data support the hypothesis that the CaSR is necessary for acid secretion, mucosal repair and the maintenance of normal G-cell numbers.

Possible function of CaSR in gastric cancer. In addition to the high level of CaSR expression in the gastrinoma, few reports have described the role of CaSR in the development of gastric diseases, particularly in the development of gastric tumors $(67,68)$. In 2007, Milne et al examined CaSR expression in primary gastric carcinomas, corresponding xenografts and two novel gastric carcinoma cell lines. The immunohistochemistry data showed no significant loss of CaSR in gastric cancers. A later analysis demonstrated that a gain in the number of CaSR was observed in primary gastric tumor cells, xenografts and cell lines (69). The author suggested that CaSR does not appear to act as a tumor suppressor gene in gastric cancer. Our laboratory data (not published) support the above views. We found that CaSR expression was significantly increased in gastric cancer patients and gastric cancer cell lines MKN45 and 7901, and the high extracellular $\mathrm{Ca}^{2+}$ can activate the CaSR to promote the proliferation and migration of gastric cancer cells. Past studies have found that high extracellular $\mathrm{Ca}^{2+}$ can mediate telomerase activity in ovarian epithelial cells (70). We speculated that CaSR might mediate this process because extracellular $\mathrm{Ca}^{2+}$ is the agonist of CaSR. We hypothesized that the same regulatory mechanism exists in the development of gastric cancer. The activated CaSR could increase human telomerase reverse transcriptase (hTERT) expression and activity via the MAPK or the PI3K/AKT signal pathways to effect the development of gastric cancer. However, we need to further test our hypothesis. In conclusion, the above results suggest that CaSR might act as a carcinogenic factor that participates in the gastric tumor development process.

\section{CaSR expression and function in the intestines}

Predominantly, research showed that CaSR is widely expressed on the surface and basal region of the colonic crypt of humans and rats (4), where it is involved in the regulation of normal intestinal epithelial cell proliferation and differentiation. In addition, rat colonic neurons comprising the enteric nervous system have also shown to have CaSR expressed on their surfaces $(71,72)$. It is suggested that CaSR agonists might act through neuronal 


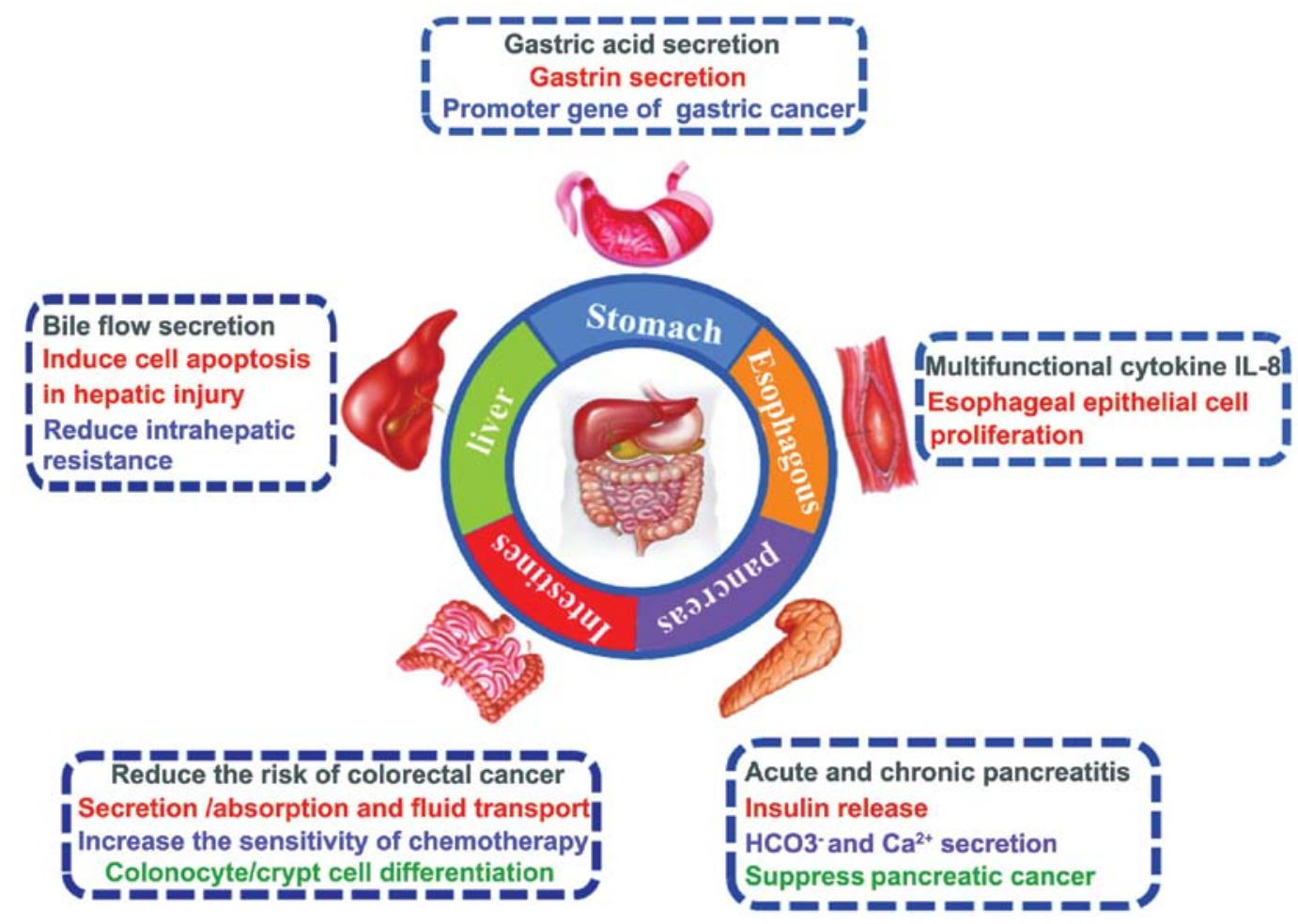

Figure 2. Summary of the known functions for the $\mathrm{Ca}^{2+}$-sensing receptor (CaSR) in the digestive system.

pathways. However, the distribution of CaSR in the colon crypt is controversial, and Chakrabarty et al indicated an increase of CaSR expression along the crypt axis, from the basal region to the top of the crypt $(34,73)$. However, Ahearn et al revealed the converse conclusion in normal mucosa of colorectal adenoma patients (74). This difference in distribution may be caused by the different genera or the functional changes in CaSR expression during the development of colonic disease.

$\mathrm{Ca}^{2+}$ and CaSR regulate intestinal secretion/absorption and fluid transport. The intestine is the main organ of nutrient absorption and secretion that adjusts the flow of water and several ions $\left(\mathrm{Na}^{+}, \mathrm{Cl}^{-}, \mathrm{K}^{+}, \mathrm{Ca}^{2+}\right)$ to maintain water and electrolyte homeostasis. Human intestinal mucosal epithelium contains a $\mathrm{Ca}^{2+}$ sensing mechanism. In the early 1980 s, changes in extracellular $\mathrm{Ca}^{2+}$ as well as modulations in 1,25-dihydroxy vitamin D3 levels were observed to regulate the absorption and/or secretion of $\mathrm{Ca}^{2+}$ in rat isolated colonic mucosa $(75,76)$. CaSR participated in the regulation of intestinal secretion and absorption associated with $\mathrm{Ca}^{2+}$, organic nutrients and amino acids. Mace et al found that CaSR was involved in the L-amino acid stimulation of enteroendocrine (IEC) K-cell and L-cell activity in the rat small intestine (77). The intestinal brush border expresses CaSR, which helps to sense the presence of intraluminal calcium and modifies calcium transcellular and paracellular absorption by co-operating with the vitamin D system (78). The presence of CaSR provides a fundamental mechanism that intestinal cells use to detect and respond to $\mathrm{Ca}^{2+}$-related biologic behavior in intestinal secretion and absorption.

In addition, the CaSR is known to play a central role in intestinal fluid transport. It was reported that colonic CaSR is activated by $\mathrm{Ca}^{2+}$ /spermine and that this activation could reverse the forskolin-stimulated net fluid secretion in isolated rat colonic crypts $(79,80)$. The secretagogues such as forskolin or cholera toxin could induce fluid secretion by three important mechanisms, including the second message addition of cAMP and cGMP, the decrease in the activity of $\mathrm{Na}^{+}$-dependent fluid absorption ion channel sodium-hydrogen exchanger (NHE) $(81,82)$, and an increase in the phosphorylation activation of $\mathrm{Cl}^{+}$-transport bumetanide-sensitive $\mathrm{Na}-\mathrm{K}-2 \mathrm{Cl}$ cotransporter (NKCC1) by CFTR (83). CaSR was shown to reverse the generous fluid secretion by increasing the NHE activity, inhibiting CFTR-NKCC1 pathway and enhancing the cyclic nucleotide destruction to abrogate the addition of cAMP and cGMP $(79,83,84)$. Thus, the presence of CaSR may have important implications for the prevention and treatment of certain diarrheal diseases. Moreover, $\mathrm{Ca}^{2+}$ and $\mathrm{CaSR}$ were required for polyamine (spermine $>$ spermidine $>$ putrescine) regulated fluid secretion. Cheng et al (85) observed in rat colonic crypts that spermine can not directly induce agonist response in the absence of $\mathrm{Ca}^{2+}$ and that the interaction of spermine with extracellular $\mathrm{Ca}^{2+}$ is able to enhance the $\mathrm{Ca}^{2+}$ sensitivity of the CaSR and modulate luminal or basolateral fluid.

The role of CaSR in colonic cancer and drug resistance. The consensus viewpoint is that CaSR as a tumor suppressor is downregulated during colorectal tumorigenesis $(86,87)$. The activation of CaSR promotes colonic cancer epithelial cell differentiation and decreases cell growth. Thus, high $\mathrm{Ca}^{2+}$ dietary intake could reduce the risk of colorectal cancer development (88). According to a previous study, the mechanisms of CaSR that suppress colon cancer were relatively clear: the cell-cell intercellular adhesion protein and epithelial-mesenchymal transition important marker E-cadherin played key roles in the CaSR-related tumorsuppressing effects in colon cancer (34). On the one hand, the increase in E-cadherin stimulated by CaSR can interact with 
$\beta$-catenin, an important protooncogene, which is the member of the Wnt pathway family that enhances the cell-cell and cell-matrix adhesion via the actin-based cytoskeleton (89). This may contribute to reducing the ability of cancer cells to move and invade surrounding tissues. On the other hand, the activation of CaSR can also prevent the nuclear translocation of $\beta$-catenin, thereby reducing $\beta$-catenin-TCF4 complex formation and downregulating the c-myc and cyclin D1 expression. This inhibits cell proliferation and the defective Wnt pathway activation in colon cancer cell lines $(34,90)$. In addition, CaSR has been reported to mediate non-canonical Wnt signaling (Wnt5a/ Ror2) and to decrease the risk of colitis-associated colon cancer by suppressing NFKB activity and reducing inflammation TNF $\alpha$ secretion and TNFR1 expression (91). Thus, there is no doubt as to the anti-oncogenic role of CaSR. Interestingly, in 2013, Singh et al found that CaSR-null colon cancer cells regained CaSR expression through the methylation and demethylation of the CaSR gene, followed by the concurrent reversal of stem cell markers, drug resistance and epithelial-mesenchymal transition (EMT) related transcription factors (92). Taken together, these data show that the inactivation of CaSR may serve as a key role in colon carcinogenesis.

In recent years, CaSR research has focused on the drug resistance of colonic cancer chemotherapy. Activated CaSR can enhance the sensitivity of human colon carcinoma cells to mitomycin C (MMC) and fluorouracil (5-FU). Cancer cells with a high level of expression of thymidylate synthase (TS) and survivin are relatively resistant to the 5-FU (93). Nevertheless, $\mathrm{NAD}(\mathrm{P}) \mathrm{H}$ :quinine oxidoreductase 1 (NQO1) is a key enzyme involved in the bioreductive activation of MMC, and its reduced level is associated with MMC resistance in colon cancer cells. The activated CaSR could up-regulate the expression of NQO1 and downregulate the expression of both TS and survivin to promote cell apoptosis during chemotherapy. The conceivable mechanism is that CaSR activation suppresses the transcriptional activation of the survivin gene by inhibiting the $\beta$-catenin/Wnt signal pathway and decreasing the formation of the T-cell factor/ $\beta$-catenin dimer (34). The dimer binding site is the survivin gene promoter $(94,95)$. Moreover, CaSR can suppress c-Myc expression to negatively affect the transcription of the TS gene $(96,97)$. In 2011, Liu et al found that CaSR could act synergistically with the voltage-activated L-type $\mathrm{Ca}^{2+}$ channel (VGCC) blocker nifedipine to increase the release of $\mathrm{Ca}^{2+}$ from intracellular stores and enhance its sensitivity to 5-FU and 5-FU metabolism (98). The human multidrug resistance 1 (MDR1) gene and the expression of its product gp170 might participate in this process (99-101). In summary, the G-proteincoupled CaSR could act as a potential target for improving the chemotherapeutic effect of colon cancer.

\section{Conclusions}

Presently evidence demonstrates that the CaSR directly or indirectly regulates a variety of aspects of gastrointestinal physiological function and disease occurrence (Fig. 2). Recently, the function of CaSR in inflammation-associated digestive disease (such as esophagitis and colitis-associated colon cancer in humans) have been a direction of new research. CaSR as a new therapeutic target for treating digestive diseases has extensive clinical significance, further research should pay more attention to the application of scientific research for clinical applications.

\section{Acknowledgements}

This study was supported by the National Natural Science Foundation of China (81301731). We also thank Professor Hui Dong (Department of Gastroenterology, Xinqiao Hospital, Third Military Medical University) for highly professional services.

\section{References}

1. Monteith GR: Calcium and cancer: targeting $\mathrm{Ca}^{2+}$ transport. Nat Rev Cancer 7: 519-530, 2007.

2. Brown EM: Role of the calcium-sensing receptor in extracellular calcium homeostasis. Best Pract Res Clin Endocrinol Metab 27: 333-343, 2013.

3. Brennan SC, Thiem U, Roth S, Aggarwal A, Fetahu ISh, Tennakoon S, Gomes AR, Brandi ML, Bruggeman F, Mentaverri R, Riccardi D and Kallay E: Calcium sensing receptor signalling in physiology and cancer. Biochim Biophys Acta 1833: 1732-1744, 2013

4. Geibel JP and Hebert SC: The functions and roles of the extracellular $\mathrm{Ca}^{2+}$-sensing receptor along the gastrointestinal tract. Annu Rev Physiol 71: 205-217, 2009.

5. Felderbauer P, Hoffmann P, Einwächter H, Bulut K, Ansorge N, Schmitz F and Schmidt WE: A novel mutation of the calcium sensing receptor gene is associated with chronic pancreatitis in a family with heterozygous SPINK1 mutations. BMC Gastroenterol 3: 34, 2003.

6. Brown EM, Gamba G, Riccardi D, Lombardi M, Butters R, Kifor O, Sun A, Hediger MA, Lytton J and Hebert SC: Cloning and characterization of an extracellular $\mathrm{Ca}(2+)$-sensing receptor from bovine parathyroid. Nature 366: 575-580, 1993.

7. Garrett JE, Capuano IV, Hammerland LG, Hung BC, Brown EM, Hebert SC, Nemeth EF and Fuller F: Molecular cloning and functional expression of human parathyroid calcium receptor cDNAs. J Biol Chem 270: 12919-12925, 1995.

8. $\mathrm{Hu} \mathrm{J}$ and Spiegel AM: Structure and function of the human calcium-sensing receptor: insights from natural and engineered mutations and allosteric modulators. J Cell Mol Med 11: 908-922, 2007.

9. $\mathrm{Hu}$ J, Hauache $\mathrm{O}$ and Spiegel AM: Human $\mathrm{Ca}^{2+}$ receptor cysteine-rich domain. Analysis of function of mutant and chimeric receptors. J Biol Chem 275: 16382-16389, 2000.

10. Huang Y, Zhou Y, Yang W, Butters R, Lee HW, Li S, Castiblanco A, Brown EM and Yang JJ: Identification and dissection of $\mathrm{Ca}(2+)-$ binding sites in the extracellular domain of $\mathrm{Ca}(2+)$-sensing receptor. J Biol Chem 282: 19000-19010, 2007.

11. Nearing J, Betka M, Quinn S, Hentschel H, Elger M, Baum M, Bai M, Chattopadyhay N, Brown EM, Hebert SC and Harris HW: Polyvalent cation receptor proteins $(\mathrm{CaRs})$ are salinity sensors in fish. Proc Natl Acad Sci USA 99: 9231-9236, 2002.

12. Canaff L and Hendy GN: Human calcium-sensing receptor gene. Vitamin D response elements in promoters $\mathrm{P} 1$ and $\mathrm{P} 2$ confer transcriptional responsiveness to 1,25-dihydroxyvitamin D. J Biol Chem 277: 30337-30350, 2002.

13. Canaff L and Hendy GN: Calcium-sensing receptor gene transcription is up-regulated by the proinflammatory cytokine, interleukin-1beta. Role of the NF-kappaB pathway and kappaB elements. J Biol Chem 280: 14177-14188, 2005.

14. Brown EM: The extracellular $\mathrm{Ca}^{2+}$-sensing receptor: central mediator of systemic calcium homeostasis. Annu Rev Nutr 20: 507-533, 2000 .

15. Ward BK, Magno AL, Walsh JP and Ratajczak T: The role of the calcium-sensing receptor in human disease. Clin Biochem 45: 943-953, 2012.

16. Dvorak MM and Riccardi D: $\mathrm{Ca}^{2+}$ as an extracellular signal in bone. Cell Calcium 35: 249-255, 2004.

17. Quarles LD: Extracellular calcium-sensing receptors in the parathyroid gland, kidney, and other tissues. Curr Opin Nephrol Hypertens 12: 349-355, 2003.

18. Wonneberger K, Scofield MA and Wangemann P: Evidence for a calcium-sensing receptor in the vascular smooth muscle cells of the spiral modiolar artery. J Membr Biol 175: 203-212, 2000 . 
19. Rácz GZ, Kittel A, Riccardi D, Case RM, Elliott AC and Varga G: Extracellular calcium sensing receptor in human pancreatic cells. Gut 51: 705-711, 2002.

20. Canaff L, Petit JL, Kisiel M, Watson PH, Gascon-Barré M and Hendy GN: Extracellular calcium-sensing receptor is expressed in rat hepatocytes coupling to intracellular calcium mobilization and stimulation of bile flow. J Biol Chem 276 : 4070-4079, 2001

21. Chow JY, Estrema C, Orneles T, Dong X, Barrett KE and Dong H: Calcium-sensing receptor modulates extracellular $\mathrm{Ca}(2+)$ entry via TRPC-encoded receptor-operated channels in human aortic smooth muscle cells. Am J Physiol Cell Physiol 301: C461-C468, 2011.

22. Breitwieser GE: Calcium sensing receptors and calcium oscillations: calcium as a first messenger. Curr Top Dev Biol 73 85-114, 2006

23. Feng SL, Sun MR, Li TT, Yin X, Xu CQ and Sun YH: Activation of calcium-sensing receptor increases TRPC 3 expression in rat cardiomyocytes. Biochem Biophys Res Commun 406: 278-284, 2011.

24. Brown EM: Clinical lessons from the calcium-sensing receptor. Nat Clin Pract Endocrinol Metab 3: 122-133, 2007.

25. Jeon US: Kidney and calcium homeostasis. Electrolyte Blood Press 6: 68-76, 2008.

26. Brown EM and MacLeod RJ: Extracellular calcium sensing and extracellular calcium signaling. Physiol Rev 81: 239-297, 2001.

27. Brennan SC and Conigrave AD: Regulation of cellular signal transduction pathways by the extracellular calcium-sensing receptor. Curr Pharm Biotechnol 10: 270-281, 2009.

28. Smrcka AV: G protein betagamma subunits: central mediators of $\mathrm{G}$ protein-coupled receptor signaling. Cell Mol Life Sci 65 : 2191-2214, 2008

29. Lin KI, Chattopadhyay N, Bai M, Alvarez R, Dang CV, Baraban JM, Brown EM and Ratan RR: Elevated extracellular calcium can prevent apoptosis via the calcium-sensing receptor. Biochem Biophys Res Commun 249: 325-331, 1998.

30. Singh N, Promkan M, Liu G, Varani J and Chakrabarty S: Role of calcium sensing receptor (CaSR) in tumorigenesis. Best Pract Res Clin Endocrinol Metab 27: 455-463, 2013.

31. Chattopadhyay N, Yano S, Tfelt-Hansen J, Rooney P, Kanuparthi D, Bandyopadhyay S, Ren X, Terwilliger E and Brown EM: Mitogenic action of calcium-sensing receptor on rat calvarial osteoblasts. Endocrinology 145: 3451-3462, 2004.

32. Kállay E, Kifor O, Chattopadhyay N, Brown EM, Bischof MG Peterlik M and Cross HS: Calcium-dependent c-myc protooncogene expression and proliferation of Caco-2 cells: a role for a luminal extracellular calcium-sensing receptor. Biochem Biophys Res Commun 232: 80-83, 1997.

33. Cifuentes M, Fuentes C, Tobar N, Acevedo I, Villalobos E, Hugo E, Ben-Jonathan $\mathrm{N}$ and Reyes $\mathrm{M}$ : Calcium sensing receptor activation elevates proinflammatory factor expression in human adipose cells and adipose tissue. Mol Cell Endocrinol 361: 24-30, 2012.

34. Chakrabarty S, Radjendirane V, Appelman H and Varani J: Extracellular calcium and calcium sensing receptor function in human colon carcinomas: promotion of E-cadherin expression and suppression of beta-catenin/TCF activation. Cancer Res 63: 67-71,2003.

35. Stoner GD, Kaighn ME, Reddel RR, Resau JH, Bowman D, Naito Z, Matsukura N, You M, Galati AJ and Harris CC: Establishment and characterization of SV40 T-antigen immortalized human esophageal epithelial cells. Cancer Res 51: 365-371, 1991

36. Justinich CJ, Mak N, Pacheco I, Mulder D, Wells RW, Blennerhassett MG and MacLeod RJ: The extracellular calcium-sensing receptor (CaSR) on human esophagus and evidence of expression of the CaSR on the esophageal epithelia cell line (HET-1A). Am J Physiol Gastrointest Liver Physio 294: G120-G129, 2008

37. Mulder DJ, Pacheco I, Hurlbut DJ, Mak N, Furuta GT, MacLeod RJ and Justinich CJ: FGF9-induced proliferative response to eosinophilic inflammation in oesophagitis. Gut 58: 166-173, 2009

38. Xing W, Li G, Xi Y, Guo J, Li H, Li H, Zhang W, Zhang L, $\mathrm{Wu} \mathrm{L}$, Wang $\mathrm{R}$ and $\mathrm{Xu} \mathrm{C}$ : The functional expression of calciumsensing receptors in BRL cells and related signal transduction pathway responsible for intracellular calcium elevation. Mol Cell Biochem 343: 13-19, 2010.
39. Xing WJ, Kong FJ, Li GW, Qiao K, Zhang WH, Zhang L, Bai SZ, Xi YH, Li HX, Tian Y, Ren H, Wu LY, Wang R and $\mathrm{Xu} C \mathrm{CQ}$ : Calcium-sensing receptors induce apoptosis during simulated ischaemia-reperfusion in Buffalo rat liver cells. Clin Exp Pharmacol Physiol 38: 605-612, 2011.

40. Sansoè G, Aragno M, Mastrocola R, Paternostro C and Parola M: Calcium receptors located in fibrotic septa: a new target to reduce portal pressure in liver cirrhosis. Clin Sci (Lond) 125: 67-75, 2013.

41. Bruce JI, Yang X, Ferguson CJ, Elliott AC, Steward MC, Case RM and Riccardi D: Molecular and functional identification of a $\mathrm{Ca}^{2+}$ (polyvalent cation)-sensing receptor in rat pancreas. J Biol Chem 274: 20561-20568, 1999.

42. Jones PM, Kitsou-Mylona I, Gray E, Squires PE and Persaud SJ: Expression and function of the extracellular calcium-sensing receptor in pancreatic beta-cells. Arch Physiol Biochem 113: 98-103, 2007.

43. Squires PE, Harris TE, Persaud SJ, Curtis SB, Buchan AM and Jones PM: The extracellular calcium-sensing receptor on human beta-cells negatively modulates insulin secretion. Diabetes 49: 409-417, 2000.

44. Parkash J: Glucose-mediated spatial interactions of voltage dependent calcium channels and calcium sensing receptor in insulin producing beta-cells. Life Sci 88: 257-264, 2011.

45. Squires PE: Non-Ca ${ }^{2+}$ homeostatic functions of the extracellular $\mathrm{Ca}^{2+}$-sensing receptor $(\mathrm{CaR})$ in endocrine tissues. J Endocrinol 165: 173-177, 2000

46. Devis G, Somers G and Malaisse WJ: Stimulation of insulin release by calcium. Biochem Biophys Res Commun 67: 525-529, 1975.

47. Gray E, Muller D, Squires PE, Asare-Anane H, Huang GC, Amiel S, Persaud SJ and Jones PM: Activation of the extracellular calcium-sensing receptor initiates insulin secretion from human islets of Langerhans: involvement of protein kinases. J Endocrinol 190: 703-710, 2006.

48. Hills CE, Younis MY, Bennett J, Siamantouras E, Liu KK and Squires PE: Calcium-sensing receptor activation increases cell-cell adhesion and beta-cell function. Cell Physiol Biochem 30: 575-586, 2012.

49. Parkash J and Asotra K: L-histidine sensing by calcium sensing receptor inhibits voltage-dependent calcium channel activity and insulin secretion in beta-cells. Life Sci 88: 440-446, 2011.

50. Whitcomb DC: Genetic aspects of pancreatitis. Annu Rev Med 61: 413-424, 2010.

51. Felderbauer P, Klein W, Bulut K, Ansorge N, Dekomien G, Werner I, Epplen JT, Schmitz F and Schmidt WE: Mutations in the calcium-sensing receptor: a new genetic risk factor for chronic pancreatitis? Scand J Gastroenterol 41: 343-348, 2006.

52. Muddana V, Lamb J, Greer JB, Elinoff B, Hawes RH, Cotton PB, Anderson MA, Brand RE, Slivka A and Whitcomb DC: Association between calcium sensing receptor gene polymorphisms and chronic pancreatitis in a US population: role of serine protease inhibitor Kazal 1 type and alcohol. World J Gastroenterol 14: 4486-4491, 2008.

53. Murugaian EE, Premkumar RM, Radhakrishnan L and Vallath B: Novel mutations in the calcium sensing receptor gene in tropical chronic pancreatitis in India. Scand J Gastroenterol 43: $117-121,2008$.

54. Aditi A, Graham DY and Vitamin C: Gastritis, and gastric disease: a historical review and update. Dig Dis Sci 57: 2504-2015, 2012.

55. Schubert ML: Gastric secretion. Curr Opin Gastroenterol 27: 536-542, 2011.

56. Prinz C, Kajimura M, Scott D, Helander H, Shin J, Besancon M, Bamberg K, Hersey S and Sachs G: Acid secretion and the H,K ATPase of stomach. Yale J Biol Med 65: 577-596, 1992.

57. Reeder DD, Conlee JL and Thompson JC: Calcium carbonate antacid and serum gastrin concentration in duodenal ulcer. Surg Forum 22: 308-310, 1971.

58. Levant JA, Walsh JH and Isenberg JI: Stimulation of gastric secretion and gastrin release by single oral doses of calcium carbonate in man. N Engl J Med 289: 555-558, 1973.

59. Hirschowitz BI, Keeling D, Lewin M, Okabe S, Parsons M, Sewing K, Wallmark B and Sachs G: Pharmacological aspects of acid secretion. Dig Dis Sci 40: 3S-23S, 1995.

60. Sachs G, Shin JM, Briving C, Wallmark B and Hersey S: The pharmacology of the gastric acid pump: the $\mathrm{H}^{+}, \mathrm{K}^{+}$ATPase. Annu Rev Pharmacol Toxicol 35: 277-305, 1995. 
61. Cheng I, Qureshi I, Chattopadhyay N, Qureshi A, Butters RR Hall AE, Cima RR, Rogers KV, Hebert SC, Geibel JP, Brown EM and Soybel DI: Expression of an extracellular calcium-sensing receptor in rat stomach. Gastroenterology 116: 118-126, 1999.

62. Ceglia L, Harris SS, Rasmussen HM and Dawson-Hughes B: Activation of the calcium sensing receptor stimulates gastrin and gastric acid secretion in healthy participants. Osteoporos Int 20: 71-78, 2009.

63. Geibel JP, Wagner CA, Caroppo R, Qureshi I, Gloeckner J, Manuelidis L, Kirchhoff P and Radebold K: The stomach divalent ion-sensing receptor scar is a modulator of gastric acid secretion. J Biol Chem 276: 39549-39552, 2001.

64. Remy C, Kirchhoff P, Hafner P, Busque SM, Müeller MK, Geibel JP and Wagner CA: Stimulatory pathways of the calcium-sensing receptor on acid secretion in freshly isolated human gastric glands. Cell Physiol Biochem 19: 33-42, 2007.

65. Rutten MJ, Bacon KD, Marlink KL, Stoney M, Meichsner CL, Lee FP, Hobson SA, Rodland KD, Sheppard BC, Trunkey DD, Deveney KE and Deveney CW: Identification of a functional $\mathrm{Ca}^{2+}$-sensing receptor in normal human gastric mucous epithelial cells. Am J Physiol 277: G662-G670, 1999.

66. Feng J, Petersen CD, Coy DH, Jiang JK, Thomas CJ, Pollak MR and Wank SA: Calcium-sensing receptor is a physiologic multimodal chemosensor regulating gastric G-cell growth and gastrin secretion. Proc Natl Acad Sci USA 107: 17791-17796, 2010

67. Itami A, Kato M, Komoto I, Doi R, Hosotani R, Shimada Y and Imamura M: Human gastrinoma cells express calcium-sensing receptor. Life Sci 70: 119-129, 2001.

68. Goebel SU, Peghini PL, Goldsmith PK, Spiegel AM, Gibril F Raffeld M, Jensen RT and Serrano J: Expression of the calcium-sensing receptor in gastrinomas. J Clin Endocrinol Metab 85: 4131-4137, 2000.

69. Milne AN, Sitarz R, Carvalho R, Polak MM, Ligtenberg M, Pauwels P, Offerhaus GJ and Weterman MA: Molecular analysis of primary gastric cancer, corresponding xenografts, and 2 novel gastric carcinoma cell lines reveals novel alterations in gastric carcinogenesis. Hum Pathol 38: 903-913, 2007.

70. Alfonso-De Matte MY, Moses-Soto H and Kruk PA: Calcium-mediated telomerase activity in ovarian epithelial cells. Arch Biochem Biophys 399: 239-244, 2002.

71. Sheinin Y, Kállay E, Wrba F, Kriwanek S, Peterlik M and Cross HS: Immunocytochemical localization of the extracellular calcium-sensing receptor in normal and malignant human large intestinal mucosa. J Histochem Cytochem 48 : 595-602, 2000.

72. Cheng SX: Calcium-sensing receptor inhibits secretagogueinduced electrolyte secretion by intestine via the enteric nervous system. Am J Physiol Gastrointest Liver Physiol 30 G60-G70, 2012.

73. Chakrabarty S, Wang H, Canaff L, Hendy GN, Appelman H and Varani J: Calcium sensing receptor in human colon carcinoma: interaction with $\mathrm{Ca}(2+)$ and 1,25-dihydroxyvitamin D(3). Cancer Res 65: 493-498, 2005.

74. Ahearn TU, McCullough ML, Flanders WD, Long Q, Sidelnikov E, Fedirko V, Daniel CR, Rutherford RE, Shaukat A and Bostick RM: A randomized clinical trial of the effects of supplemental calcium and vitamin D3 on markers of their metabolism in normal mucosa of colorectal adenoma patients. Cancer Res 71: 413-423, 2011.

75. Favus MJ, Kathpalia SC and Coe FL: Kinetic characteristics of calcium absorption and secretion by rat colon. Am J Physiol 240: G350-G354, 1981.

76. Favus MJ, Kathpalia SC, Coe FL and Mond AE: Effects of diet calcium and 1,25-dihydroxyvitamin D3 on colon calcium active transport. Am J Physiol 238: G75-G78, 1980.

77. Mace OJ, Schindler M and Patel S: The regulation of K- and L-cell activity by GLUT2 and the calcium-sensing receptor CasR in rat small intestine. J Physiol 90: 2917-2936, 2012.

78. Garg MK, Kalra S and Mahalle N: The intestinal calcistat: Determinant of clinical vitamin D deficiency. Indian J Endocrinol Metab 17: 780-783, 2013.

79. Geibel J, Sritharan K, Geibel R, Geibel P, Persing JS, Seeger A, Roepke TK, Deichstetter M, Prinz C, Cheng SX, Martin D and Hebert SC: Calcium-sensing receptor abrogates secretagogueinduced increases in intestinal net fluid secretion by enhancing cyclic nucleotide destruction. Proc Natl Acad Sci USA 103: 9390-9397, 2006.

80. Cheng SX, Okuda M, Hall AE, Geibel JP and Hebert SC: Expression of calcium-sensing receptor in rat colonic epithelium: evidence for modulation of fluid secretion. Am J Physiol Gastrointest Liver Physiol 283: G240-G250, 2002.
81. Kunzelmann $\mathrm{K}$ and Mall M: Electrolyte transport in the mammalian colon: mechanisms and implications for disease. Physiol Rev 82: 245-289, 2002.

82. Donowitz, $\mathrm{M}$ and Welsh MJ: $\mathrm{Ca}^{2+}$ and cyclic AMP in regulation of intestinal $\mathrm{Na}, \mathrm{K}$, and $\mathrm{Cl}$ transport. Annu Rev Physiol 48 $135-150,1986$

83. Haas M and Forbush B III: The Na-K-Cl cotransporter of secretory epithelia. Annu Rev Physiol 62: 515-534, 2000.

84. Beavo JA: Cyclic nucleotide phosphodiesterases: functional implications of multiple isoforms. Physiol Rev 75: 725-748, 1995.

85. Cheng SX, Geibel JP and Hebert SC: Extracellular polyamines regulate fluid secretion in rat colonic crypts via the extracellular calcium-sensing receptor. Gastroenterology 126: 148-158, 2004.

86. Rogers AC, Hanly AM, Collins D, Baird AW and Winter DC: Review article: loss of the calcium-sensing receptor in colonic epithelium is a key event in the pathogenesis of colon cancer. Clin Colorectal Cancer 11: 24-30, 2012.

87. Bresalier RS: Calcium, chemoprevention, and cancer: a small step forward (a long way to go). Gastroenterology 116: 1261-1263, 1999.

88. Lamprecht SA and Lipkin M: Cellular mechanisms of calcium and vitamin $\mathrm{D}$ in the inhibition of colorectal carcinogenesis. Ann NY Acad Sci 952: 73-87, 2001

89. Brembeck FH, Rosario M and Birchmeier W: Balancing cell adhesion and Wnt signaling, the key role of beta-catenin. Curr Opin Genet Dev 16: 51-59, 2006.

90. MacLeod RJ, Hayes M and Pacheco I: Wnt5a secretion stimulated by the extracellular calcium-sensing receptor inhibits defective Wnt signaling in colon cancer cells. Am J Physiol Gastrointest Liver Physiol 293: G403-G411, 2007.

91.Kelly JC, Lungchukiet P and Macleod RJ: Extracellular calcium-sensing receptor inhibition of intestinal epithelial TNF signaling requires CaSR-mediated Wnt5a/Ror2 interaction. Front Physiol 2: 17, 2011.

92. Singh $\mathrm{N}$ and Chakrabarty S: Induction of CaSR expression circumvents the molecular features of malignant CaSR null colon cancer cells. Int J Cancer 133: 2307-2314, 2013.

93. Liu G, Hu X, Varani J and Chakrabarty S: Calcium and calcium sensing receptor modulates the expression of thymidylate synthase, NAD(P)H:quinone oxidoreductase 1 and survivin in human colon carcinoma cells: promotion of cytotoxic response to mitomycin C and fluorouracil. Mol Carcinog 48: 202-211, 2009.

94. Kim PJ, Plescia J, Clevers H, Fearon ER and Altieri DC: Survivin and molecular pathogenesis of colorectal cancer. Lancet 362: 205-209, 2003.

95. Van de Wetering M, Oosterwegel M, Dooijes D and Clevers H: Identification and cloning of TCF-1, a T lymphocyte-specific transcription factor containing a sequence-specific HMG box. EMBO J 10: 123-132, 1991

96. Lincz LF, Scorgie FE, Garg MB and Ackland SP: Identification of a novel single nucleotide polymorphism in the first tandem repeat sequence of the thymidylate synthase $2 \mathrm{R}$ allele. Int $\mathrm{J}$ Cancer 120: 1930-1934, 2007.

97. Akopov SB, Chernov IP, Wahlström T, Kostina MB, Klein G, Henriksson $\mathrm{M}$ and Nikolaev LG: Identification of recognition sites for $\mathrm{myc} / \mathrm{max} / \mathrm{mxd}$ network proteins by a whole human chromosome 19 selection strategy. Biochemistry (Mosc) 73: 1260-1268, 2008

98. Liu G, Hu X, Premkumar L and Chakrabarty S: Nifedipine synergizes with calcium in activating the calcium sensing receptor, suppressing the expression of thymidylate synthase and survivin and promoting sensitivity to fluorouracil in human colon carcinoma cells. Mol Carcinog 50: 922-930, 2011.

99. Hunter J, Hirst BH and Simmons NL: Epithelial secretion of vinblastine by human intestinal adenocarcinoma cell (HCT-8 and T84) layers expressing P-glycoprotein. Br J Cancer 64: 437-444, 1991

100. Gottesman MM, Pastan I and Ambudkar SV: P-glycoprotein and multidrug resistance. Curr Opin Genet Dev 6: 610-617, 1996

101. Rimet O, Mirrione A and Barra Y: Multidrug-resistant phenotype influences the differentiation of a human colon carcinoma cell line. Biochem Biophys Res Commun 259: 43-49, 1999. 